\title{
Effects of Plant Tannin Extracts Supplementation on Animal Performance and Gastrointestinal Parasites Infestation in Steers Grazing Winter Wheat
}

\author{
B. R. Min ${ }^{1,2}$, K. Hernandez ${ }^{3}$, W. E. Pinchak ${ }^{1}$, R. C. Anderson ${ }^{4}$, J. E. Miller ${ }^{5}$, E. Valencia ${ }^{3}$ \\ ${ }^{1}$ Texas Agricultural Experiment Station, Vernon, USA \\ ${ }^{2}$ Tuskegee University, Tuskegee, USA \\ ${ }^{3}$ College of Agricultural Sciences, University of Puerto Rico, Mayaguez, Puerto Rico \\ ${ }^{4}$ United States Department of Agriculture, Agricultural Research Service, Southern Plains Agricultural Research \\ Center, Food and Feed Safety Research Unit, College Station, USA \\ ${ }^{5}$ Department of Pathological Science, School of Veterinary Medicine, Louisiana State University, Baton Rouge, \\ USA \\ Email: ${ }^{\text {bpinchak@ag.tamu.edu }}$
}

Received 23 June 2015; accepted 19 July 2015; published 22 July 2015

Copyright (C) 2015 by authors and Scientific Research Publishing Inc.

This work is licensed under the Creative Commons Attribution International License (CC BY).

http://creativecommons.org/licenses/by/4.0/

(c) (i) Open Access

\section{Abstract}

Twenty-six stocker cattle $(286.1 \pm 25.7 \mathrm{~kg})$ were used to quantify the effect of commercial plant tannin extracts (control vs. mimosa and chestnut tannins) on animal performance, gastrointestinal parasites control and plasma metabolite changes in heifers grazing winter wheat forage (Triticum aestivum L. var. "cutter"). The forage biomass and crude protein content were generally similar among treatments. Initial live-weight (LW) was similar among treatments, although final LW ( $P$ $=0.1)$ and average daily gain $(A D G ; P<0.01)$ differed. Logarithmic $(\log )$ fecal egg counts (FEC) for Haemonchus contortus was higher $(P<0.02)$ for mimosa tannins group than for control group, and chestnut tannins group was intermediate in cattle grazing wheat forage on day 35 . Logarithmic FEC for Ostertagia was lower $(P<0.05)$ for chestnut tannins group than for both control and mimosa tannins group on day 41. However, log FEC for Cooperia was lower $(P<0.04)$ for mimosa tannins than for both control and chestnut tannins group. Blood parameters were similar among treatments, except cholesterol level on day 70 . Blood cholesterol level was higher $(P<0.02)$ for chestnut tannins group than for control, and intermediate for mimosa tannins. However, choles-

\footnotetext{
${ }^{*}$ Corresponding author.

How to cite this paper: Min, B.R., Hernandez, K., Pinchak, W.E., Anderson, R.C., Miller, J.E. and Valencia, E. (2015) Effects of Plant Tannin Extracts Supplementation on Animal Performance and Gastrointestinal Parasites Infestation in Steers Grazing Winter Wheat. Open Journal of Animal Sciences, 5, 343-350. http://dx.doi.org/10.4236/ojas.2015.53038
} 
terol level was similar among treatment after 20 days cessation of tannins treatments. Our data suggest that heifers grazing winter wheat forage supplemented with plant tannins rather than control (non-tannins group) increased ADG (8\% to $19 \%$ ) for mimosa and chestnut tannins groups, respectively with no detectable detrimental effects on animal health. The increase in ADG may be due to decrease fecal parasites infections.

\title{
Keywords
}

\author{
Average Daily Gain, Gastrointestinal Parasites, Steer, Tannins
}

\section{Introduction}

Gastrointestinal parasite infections are natural occurring components of pastoral grazing systems and many internal parasite species have developed resistance to anthelmintic drugs [1]. Gastrointestinal parasites infection cause major production losses in grazing cattle with the greatest reduction occurring in young growing cattle, which normally have limited immunity to nematode parasites [2]-[4]. Choosing yearling stocker cattle as an internal parasites infestation model allows the extension of our model to broad range of stocker cattle production systems in Southern US. Alternative anthelmintic chemistries are needed even in conventional systems because of increasing parasite resistance to contemporary synthetic anthelmintics [1] [5].

Natural plant tannins have been documented to control intestinal parasites in ruminants [6] [7]. Molan et al. [8] [9] have shown that tannin extracted from forages had the ability to inhibit the larval motility and eggs hatching rate in vitro. Previous scientific reviews have shown that a threshold of at least $2 \%$ to $4 \%$ tannins per kg dry matter in diet has to be reached to observe anti-parasitic activity [6] [10]. It has been shown that condensed tannins (quebracho tannins; $40 \mathrm{~g} / \mathrm{kg}$ body weight) was ineffective in sheep against the Trichinella spiralis nematode, whereas worm burdens of Nippostrongylus brasiliensis were significantly reduced [11]. However, the excess consumption of plant tannins extracts can be negatively affected host animals. Studies need to be carried out worldwide, to identify tannin compounds and the associated mechanisms of their mode of actions understood, in order to determine for their use in internal parasites control.

The benefits of tannins in the diets to affect digestion of tannins-free diets have facilitated research involving other dietary tannins compounds such as commercially available mimosa and chestnut tannins. We hypothesize commercially available plant tannin extracts would be effective in controlling internal parasites infestation and increasing average daily gain (ADG) in growing stocker cattle. The objectives of this study were to examine the animal performance, internal parasites, and blood metabolites effects of hydrolysable tannin-rich chestnut and condensed tannin-rich mimosa extracts applied as a feed additive to stocker cattle.

\section{Materials and Methods}

\subsection{Experimental Design and Protocol}

Twenty-six stocker cattle (Angus $\times$ Hereford $\times$ Brangus; $286.1 \pm 25.7 \mathrm{~kg}$ ) were used to quantify the effect of plant tannins (control vs. mimosa and chestnut tannins) on animal performance and animal health (internal parasites and plasma metabolites) in heifers grazing winter wheat forage. Animals were randomly allocated to 1 of 3 treatments that included a control (non-tannins group; texture feed only) and two types of tannins (mimosa and chestnut tannins). The study was conducted at the West Walker Unit of the Texas Agricultural Research Center, Vernon, TX from February to April during 70 days. After a 30 day adjustment period to grazing wheat forage, cattle were dewormed (Moxidectin; $10 \mathrm{~mL} / 100 \mathrm{~kg}$ BW; Fort Dodge Animal Health, Fort Dodge, Iowa). Cattle were weighted at 10 days intervals. Plant tannins (1.5\% of DMI) were supplemented by once daily mixing extract with a textured feed carrier (500 g/steer) at approximately $0800 \mathrm{~h}$. The mixed ration consisted of steamflaked milo (85 kg), hominy feed (10 kg), and molasses (5 kg/100kg DM) on an as-feed basis.

\subsection{Experimental Parasites Infection and Fecal Egg Counts}

Two weeks after treated with Moxidectin, all animals were experimentally-infected (March 15) with infective 
stage of larvae $\left(\mathrm{L}_{3}\right)$ by a single feed-through infection mixed with Cooperia (3000), Ostertagia ostertagi (2000), and Haemonchus contortus (1000) larvae per animal (day 0). The nematodes larvae were collected from infected donor cattle and provided by Dr. J. E. Miller, Louisiana State University, LA. Individual parasites larvae and fecal eggs were morphologically confirmed according to the methods of Merck Veterinary Manual [12] [13].

Fecal samples $(n=4)$ were collected (every 10 to 15 days) rectally and examined for fecal egg counts (FEC; [13]).

Blood samples was taken $(5 \mathrm{ml})$ and analyzed by Vet Scan (Mammalian Liver Profile; VS2; 3240 Whipple Rd., Union City, CA) to quantify Alkaline phosphatase (liver, bone, parathyroid, and intestinal disease), Alanine aminotransferase (liver and heart diseases including viral hepatitis and cirrhosis), Gamma glutamyl transferase (primary and secondary liver tumors), bile acids (hepatobiliary disease), total bilirubin (hepatic disorders), blood urea nitrogen (liver and kidney disease), and total cholesterol levels. The endoscopic examination (Olympus CLK-3; Cold light supply, Olympus Optical Co. Ltd., Japan) from esophagus were performed all the animals with a local veterinary (Vernon, Vet Clinic, Vernon, TX) at the end of trial and 30 days after the cessation of experiment to quantify any lesions related to tannin extract supplementation.

\subsection{Statistical Analyses}

Data from each experiment were analyzed by the MIXED procedure (SAS Institute, Cary, N.C.), and differences in log mean $\mathrm{FEC} / \mathrm{mg}$ was determined by a repeated-measures analysis of variance. The variables in experiment included forage chemical composition, live-weight (LW), average daily gain (ADG), FEC, and plasma blood parameters. The model included sources of plant extracts (mimosa vs. chestnut tannins) and time. The replicate was treated as a random variable. The FEC was log transformed prior to analysis.

\section{Results}

\subsection{Forage Mass, Forage Chemical Composition and Body Weight Gain}

Animals were grazed during a vegetative state and early reproductive stage of wheat forage during the experiment. The forage biomass and crude protein content were generally similar among treatments (Table 1). Initial LW was similar among treatments, although final LW $(P=0.1)$ and ADG $(P<0.01)$ were differed (Table 1$)$.

\subsection{Fecal Egg Counts}

There was no significant interaction between date and source of tannins on FEC. Logarithmic FEC for $\mathrm{H}$. contortus was greater $(P<0.02)$ for mimosa tannins group than for control group, and chestnut tannins group was intermediate after day 35 (Table 2), indicating that those tannins supplemented at $1.5 \%$ DMI did not inhibit $H$. contortus larval establishment in host animals. Logarithmic FEC for O. ostertagi was lower $(P<0.05)$ for chestnut tannins group than for control group on day 41. In comparison, log FEC for Cooperia was lower $(P<$ 0.04) for mimosa tannins than for control group.

\subsection{Effects of Plant Tannins on the Blood Parameters and Endoscopic Examination}

As shown in Table 3, blood parameters were similar among treatments, except cholesterol level on day 70.

Table 1. Forage chemical composition, biomass and animal body weight (BW) change, and average daily gain (ADG) in steers grazing winter wheat (February 13 to April 24), Vernon, TX.

\begin{tabular}{cccccc}
\hline Item & MCT & CCT & Control & SEM & $P$-value \\
\hline Biomass (kg DM/ha) & 1283 & 1032 & 1141 & 122.2 & 0.25 \\
Crude protein (\%) & 22.8 & 23.5 & 22 & 1.33 & 0.57 \\
BW change (70 day) & & & & 0.83 \\
Initial BW & 325.1 & 335.4 & 331.3 & 15.59 & 0.1 \\
Final BW & 408.7 & 434.8 & 399.5 & 17.5 & 0.01 \\
ADG (g/day) & $1.84^{\text {ab }}$ & $2.1^{\text {a }}$ & $1.7^{\text {b }}$ & 0.12 & 0.01 \\
\hline
\end{tabular}

MCT: mimosa tannins, CCT: chestnut tannins. ${ }^{\text {ab, }, \mathrm{c}}$ Numbers in a row with superscript letters are significantly different $(P<0.05)$. 
Table 2. Logarithmic means of Haemonchus contortus, Ostertagia ostertagi, and Cooperia fecal egg counts in steers grazing winter wheat forage with or without supplementation of commercial tannins.

\begin{tabular}{|c|c|c|c|c|c|}
\hline Item & Control & Mimosa & Chestnut & SEM & $P$-value \\
\hline \multicolumn{6}{|l|}{ Haemonchus contortus } \\
\hline Day 0 & 0.51 & 0.46 & 0.21 & 0.16 & 0.74 \\
\hline Day 20 & 0.37 & 0.85 & 0.64 & 0.16 & 0.22 \\
\hline Day 35 & $0.57^{\mathrm{c}}$ & $1.44^{\mathrm{a}}$ & $1.06^{\mathrm{ab}}$ & 0.16 & 0.02 \\
\hline Day 41 & 0.26 & 0.21 & 0.21 & 0.16 & 0.58 \\
\hline SEM & 0.14 & 0.14 & 0.14 & - & - \\
\hline \multicolumn{6}{|l|}{ Ostertagia ostertagi } \\
\hline Day 0 & 0.57 & 0.16 & 0.59 & 0.22 & 0.32 \\
\hline Day 20 & 0.77 & 0.59 & 0.77 & 0.22 & 0.66 \\
\hline Day 35 & 1.24 & 1.57 & 1.71 & 0.22 & 0.26 \\
\hline Day 41 & $0.40^{\mathrm{a}}$ & $0.40^{\mathrm{a}}$ & $0.17^{\mathrm{b}}$ & 0.22 & 0.05 \\
\hline SEM & 0.19 & 0.19 & 0.19 & - & - \\
\hline \multicolumn{6}{|l|}{ Cooperia + others } \\
\hline Day 0 & 0.56 & 0.73 & 0.21 & 0.13 & 0.13 \\
\hline Day 20 & 1.73 & 2.14 & 1.81 & 0.13 & 0.19 \\
\hline Day 35 & $4.28^{\mathrm{a}}$ & $3.63^{\mathrm{b}}$ & $4.26^{\mathrm{a}}$ & 0.13 & 0.04 \\
\hline Day 41 & $3.97^{\mathrm{a}}$ & $3.47^{\mathrm{b}}$ & $3.66^{\mathrm{b}}$ & 0.14 & 0.12 \\
\hline SEM & 0.1 & 0.12 & 0.12 & - & - \\
\hline Interaction & $\mathrm{HC}$ & OS & Cooperia & & \\
\hline Date (D) & 0.001 & 0.001 & 0.001 & & \\
\hline Sources of tannins $(\mathrm{T})$ & 0.16 & 0.64 & 0.57 & & \\
\hline $\mathrm{D} \times \mathrm{T}$ & 0.69 & 0.78 & 0.11 & & \\
\hline
\end{tabular}

Steers were grazed winter wheat forage during the 70 days with and without tannins supplementation. Infective third ( $\left.\mathrm{L}_{3}\right)$ stage of larvae mixtures Haemonchus contortus (HC), Ostertagia ostertagi (OS), and Cooperia were artificially infected with feed through. ${ }^{\text {a,b,c }}$ Numbers in a row with superscript letters are significantly different $(P<0.05)$.

Blood cholesterol level was higher $(P<0.02)$ for chestnut tannins group than for control, and intermediate for mimosa tannins. However, cholesterol level was similar among treatments after 20 days cessation of tannins treatments. After 20 days cessation of tannins treatment, total bilirubin was higher $(P<0.02)$ for mimosa than for control, while blood urea nitrogen was higher $(P<0.02)$ for control than for chestnut tannins group.

Esophageal endoscopic evaluation of all cattle at the end of the trial (day 70) indicated that heifers received with or without plant tannins had no lesions observed on esophagus measured by endoscopic examination (Data not shown).

\section{Discussion}

The most significant findings in this study were that heifers grazing winter wheat forage supplemented with plant tannins rather than control (non-tannins group) 8\% to 19\% increased ADG for mimosa and chestnut tannins groups, respectively with no discernable detrimental effects on blood chemistry or the esophagus. The increase in ADG may be due to decreases in both Cooperia and $O$. ostertagi fecal parasites infections. The significant reduction of FEC in both Cooperia and O. ostertagi after day 35 or 41 suggests that length of feeding time is required to give maximum response in internal parasites infestation. 
Table 3. The effect of plant tannins supplementation on plasma blood parameters in steers grazing winter wheat forage.

\begin{tabular}{|c|c|c|c|c|c|c|c|c|}
\hline Control & Control & Mimosa & Chestnut & SEM & \multicolumn{4}{|l|}{$P$-value } \\
\hline \multicolumn{9}{|c|}{$\begin{array}{l}\text { Tannins treatment period } \\
\text { (after } 70 \text { days tannins administration) }\end{array}$} \\
\hline ALP & 181.6 & 180.9 & 162 & 63.57 & 0.76 & & & \\
\hline ALT & 30.2 & 31.6 & 29.4 & 2.51 & 0.41 & & & \\
\hline GGT & 11.2 & 13.1 & 13.3 & 2.51 & 0.39 & & & \\
\hline BA & 6.9 & 8.6 & 3 & 1.91 & 0.25 & & & \\
\hline TBIL & 0.69 & 0.69 & 0.71 & 0.03 & 0.61 & & & \\
\hline ALB & 2 & 2 & 1.9 & 0.04 & 0.49 & & & \\
\hline BUN & 12.7 & 13.6 & 12.4 & 0.52 & 0.38 & & & \\
\hline CHOL & $62.6^{\mathrm{b}}$ & $71.2^{\mathrm{ab}}$ & $90.4^{\mathrm{a}}$ & 10.6 & 0.02 & & & \\
\hline \multicolumn{9}{|c|}{ Non-tannins treatment period } \\
\hline \multicolumn{9}{|c|}{$\begin{array}{l}\text { (20 days cessation of tannins } \\
\text { administration on wheat pasture) }\end{array}$} \\
\hline ALP & 149.8 & 135.1 & 129.3 & 24.8 & 0.73 & & & \\
\hline ALT & 24.1 & 24.8 & 23.5 & 2.57 & 0.66 & & & \\
\hline GGT & 9.8 & 13.7 & 11.6 & 2.61 & 0.45 & & & \\
\hline BA & 19.1 & 13.8 & 14.2 & 1.91 & 0.3 & & & \\
\hline TBIL & $0.48^{\mathrm{b}}$ & $0.61^{\mathrm{a}}$ & $0.50^{\mathrm{b}}$ & 0.04 & 0.02 & & & \\
\hline ALB & 2 & 1.9 & 1.8 & 0.05 & 0.38 & & & \\
\hline BUN & $11.1^{\mathrm{a}}$ & $10.7^{\mathrm{a}}$ & $7.9^{\mathrm{b}}$ & 0.52 & 0.02 & & & \\
\hline CHOL & 54 & 73 & 63.2 & 13.4 & 0.37 & & & \\
\hline Interaction & ALP & ALT & GGT & BA & TBIL & ALB & BUN & CHOL \\
\hline Period (P) & 0.3 & 0.01 & 0.58 & 0.001 & 0.001 & 0.34 & 0.001 & 0.14 \\
\hline Source of tannins $(\mathrm{T})$ & 0.89 & 0.7 & 0.36 & 0.42 & 0.13 & 0.63 & 0.07 & 0.16 \\
\hline $\mathrm{P} \times \mathrm{T}$ & 0.98 & 0.97 & 0.81 & 0.53 & 0.09 & 0.38 & 0.28 & 0.29 \\
\hline
\end{tabular}

Steers were grazed winter wheat forage during the 70 days with tannins supplementation. Animals were continues grazed on wheat forage after the cessation of tannins administration, and the last blood samples were taken 20 days thereafter. Alkaline phosphatase (ALP), liver, bone, parathyroid and intestinal disease; alanine aminotransferase (ALT), liver diseases including viral hepatitis, cirrhosis, and heart diseases; gamma glutamyl transferase (GGT), liver disease, primary and secondary liver tumors; bile acids (BA), hepatobiliary disease, portosystemic anomaly, and extraheptic; total bilirubin (TBIL), hepatic disorders; albumin, liver and kidney disease; blood urea nitrogen (BUN), liver and kidney disease; total cholesterol (CHOL).

${ }^{\mathrm{a}, \mathrm{b}, \mathrm{c}}$ Numbers in a row with superscript letters are significantly different $(P<0.05)$.

In the present study, both mimosa and chestnut tannins did not have inhibiting effect on $H$. contortus fecal egg output, but Cooperia and Ostertagia fecal egg output were reduced in heifers supplemented with both tannin extracts. When established adult nematodes were exposed to condensed tannins in sheep, a reduction in worm fecundity and worm numbers was observed for the intestinal species (Nematodirus battus and Trichostrongylus colubriformis), whereas no changes were recorded for the species that resides in the stomach and abomasums (Teladorsagia circumcincta and H. contortus; [14]). It has been shown that dietary quebracho tannins (40 g/kg LW) was ineffective in sheep against the mucosal dewelling nematode, Trichinella spiralis, whereas worm burdens of Nippostrongylus brasiliensis, a lumen dweller, were significantly reduced [11]. It is possible that the effectiveness of plant tannin extracts against $H$. contortus may due to the short time period that the larvae were exposed to gut contents before embedding in the small intestinal mucosa, known to be $<30$ min [11], indicating that direct contact between the tannins and the nematodes may be necessary in order to reduce worm burden or 
larval establishment in host animals. Conversely, Min et al. [7] reported that condensed tannins-containing Sericea lespedeza (15.2\% condensed tannins) diet in goats reduced $89 \%$ of $H$. contortus population in the abomasums than those grazing non-tannins containing forage, indicating that possibility of direct or indirect mechanisms, increase protein supply and immune response against worms, contributing to the anthelmintic properties of different types of tannins cannot be discards.

Cooperia fecal eggs were reduced $8 \%$ to $13 \%$ by mimosa and chestnut tannins supplementation, respectively. While present study has shown that average Ostertagia fecal eggs production can be reduced by $57 \%$ on day 41 without use of anthelmintics when heifers received chestnut tannins as compared to a non-tannins containing diet. This reduction is an indication that plant tannins supplementation has an anthelmintic potential to control internal parasites in ruminants depending on sources of tannins and nematode species. Yamasaki et al. [15] reported that substantial toxic effects have been detected in the digestive and reproductive tracts of Caenorhabditis elegans worms after contact with hydrolysable ellagic tannins. Similar lesions and shrinkages of the cuticle surface of adult $T$. colubriformis after incubation in a chestnut extract $(1.2 \mathrm{mg} / \mathrm{ml})$ in phosphate buffer solution have been shown in in vitro [10], indicating that plant tannins, especially hydrolysable tannins, could directly affect the cuticle surface of worms or change their physical and biological process. Plant tannins could act indirectly, by improving the response of the host to parasites. Few studies, however, have addressed this indirect hypothesis by measuring specifically local or general parameters related to host immunity, and the results remain fundamentally inconclusive.

There is strong evidence showing that an improved efficiency of protein digestion throughout tannins-containing forage diet, especially by-pass protein from the rumen, can result in an increased ADG and animal productivity [16] [17]. The importance of plant tannins and protein digestion was confirmed by Min et al. [7] [18] [19], who found that $1.5 \%$ condensed tannins (quebracho) supplementation in steers grazing wheat forage increased ADG by 15\%. Recently, Min et al. [18]-[20] found that cattle grazing high quality wheat forage and feeding plant tannins were associated with ADG, altered rumen metabolites and microbial populations [21]. Condensed tannins-containing forage diets in sheep have been previously shown to decrease proteolysis of high quality forage, but increased by-pass protein [16] [17]. It therefore seems possible that the increased supply of protein and reduced internal parasite infestation caused by the action of tannins could be used to increase animal production system in grazing cattle with minimum anthelmintic drug usage in grazing ruminants. Studies are required to know the optimum levels of tannins in order to have this positive response. The concentration of tannins should not be high enough so that the true digestibility of the substrate is appreciably decreased.

Ingestion of phenolic compounds such as tannins have been shown to various gastrointestinal disturbances. Hervas et al. [22] reported that condensed tannins (quebracho) extract diet was not toxic in terms of digestive tract (abomasums, small intestine, mucous and caecum) and plasma chemistry examinations in sheep supplemented less than $1.5 \mathrm{~g} / \mathrm{kg} \mathrm{LW}$ or less than $83 \mathrm{~g} / \mathrm{kg} \mathrm{DM}$ a day. However, sheep received condensed tannins up to $3 \mathrm{~g} / \mathrm{kg} \mathrm{LW}$ or $188 \mathrm{~g} / \mathrm{kg} / \mathrm{DM}$ a day, animals showed striking lesions in the digestive track, and changes in plasma biochemistry. Consumption of a small amount of mimosa tannins daily (3.5 g/kg DM) in diary cows (461 kg LW) does not cause toxic effects or does not negative affect cows performance, but depressed plasma urea concentrations [23]. It has been shown that consumption of a small amount of hydrolysable chestnut tannins daily $(20.8 \mathrm{~g} / \mathrm{kg} \mathrm{DM})$ in lambs (15 - $25 \mathrm{~kg} \mathrm{LW})$ does not cause toxic effects or does not negatively affect lamb performance [24]. Most of hydrolysable tannins toxicosis is natural poisonings documented in cattle consuming oak tree leaves [25] and the actual levels of hydrolysable tannins consumed are seldom reported. Krisper et al. [26] reported that large quantities of chestnut tannins were toxic to the liver and kidney, but no detrimental effects (liver, kidney, stomach, and small intestine tissue) observed when chestnut tannins fed to piglets and rats during 28 days. In the present study, $1.5 \%$ mimosa and chestnut tannins supplementations per kg dry matter intake in heifers does not negatively affected in cattle blood chemistry, except plasma cholesterol level. Cattle fed 1.5\% chestnut tannins diet over the 70 days increased plasma cholesterol level, but mimosa tannins did not, indicating that hydrolysable tannins may be affected lipid metabolism by unknown mechanisms. It is conceivable, as previously suggested [27], that volatile fatty acids and particularly propionate plays a hypocholestrolemic role. However, it remains that a direct effect of the physiological concentrations of VFA and plant tannins on hepatic cholesterogenesis is still uncertain in ruminants. These studies also indicate that feeding low level $(<1.5 \%$ tannins/DMI) of plant tannins to ruminants may has no detrimental effects. 


\section{Conclusion}

It was concluded that heifers grazing winter wheat forage received plant tannins increased ADG with generally no detrimental effects. The increase in ADG may be due to decrease fecal parasites infections.

\section{References}

[1] Kaplan, R.M. (2004) Drug Resistance in Nematodes of Veterinary Importance: A Status Report. Trends in Veterinary, 20, 477-481. http://dx.doi.org/10.1016/j.pt.2004.08.001

[2] Craig, T.M. (1988) Impact of Internal Parasites on Beef Cattle. Journal of Animal Science, 55, 1565-1569.

[3] Parkins, J.J. and Holmes, P. (1989) Effects of Gastrointestinal Helminth Parasites on Ruminant Nutrition. Nutrition Research Reviews, 2, 227-246. http://dx.doi.org/10.1079/NRR19890016

[4] Stuedemann, J.A., Kaplan, R.M., Miller, J.E. and Seman, D.H. (2005) Importance of Nematode Parasites in Cattle Grazing Research. Proceedings of the 59th Southern Pasture and Forage Crop Improvement Conference, Philidelphia.

[5] Prichard, R. (1994) Antihelminthic Resistance. Veterinary Parasitology, 54, 259-268. http://dx.doi.org/10.1016/0304-4017(94)90094-9

[6] Min, B.R. and Hart, S.P. (2003) Tannins for Suppression of Internal Parasites. Journal of Animal Science, 81, E102E109.

[7] Min, B.R., Hart, S.P., Miller, D., Tomita, G.M., Loetz, E. and Sahlu, T. (2005) The Effect of Grazing Forage Containing Condensed Tannins on Gastro-Intestinal Parasite Infection and Milk Composition in Angora Does. Veterinary Parasitology, 130, 105-113. http://dx.doi.org/10.1016/j.vetpar.2005.03.011

[8] Molan, A.L., Waghorn, G.C. and McNabb, W.C. (1999) Condensed Tannins and Parasites. Proc. N.Z. Grassland Sco., 61, 57-61.

[9] Molan, A.L., Waghorn, G.C., Min, B.R. and McNabb, W.C. (2000) The Effect of Condensed Tannins from the Seven Herbages on Trichostrongylus colubrifomis Larval Migration in Vitro. Folia Parasitologica, 47, 39-44. http://dx.doi.org/10.14411/fp.2000.007

[10] Hoste, H., Jackson, F., Athanasiadou, S., Thamsborg, S.M. and Hoskin, S.O. (2006) The Effects of Tannin-Rich Plants on Parasitic Nematodes in Ruminants. Trends in Parasitology, 22, 253-261. http://dx.doi.org/10.1016/j.pt.2006.04.004

[11] Butter, N.L., Dawson, J.M., Wakelin, D. and Buttery, P.J. (2001) Effect of Dietary Condensed Tannins on Gastrointestinal Nematodes. The Journal of Agricultural Science, 137, 461-469. http://dx.doi.org/10.1017/S0021859601001605

[12] Merck Veterinary Manual (MVM) (2006) Gastrointestinal Parasites of Ruminants. Merck \& Co., Inc., Whitehouse Station. http://www.merckvetmanual.com/mvm/index.jsp

[13] Zajac, A.M. (1994) Fecal Examination in the Diagnosis of Parasitism. In: Sloss, M.W., Kemp, R.L. and Zajac, A.M., Eds., Veterinary Clinical Parasitology, American Association of Veterinary Parasitologists, Iowa State University Press, Iowa City, 3-63.

[14] Min, B.R., McNabb, W.C., Barry, T.N., Kemp, P.D., Waghorn, G.C. and McDonald, M.F. (1999) The Effect of Condensed Tannins in Lotus Corniculatus upon Reproductive Efficiency and Wool Production in Sheep during Late Summer and Autumn. The Journal of Agricultural Science, 132, 323-334. http://dx.doi.org/10.1017/S0021859699006371

[15] Yamasaki, T., Sato, M., Mori, T., Mohamed, A.S., Fujii, K. and Tsukioka, J. (2002) Toxicity of Tannins towards the Free-Living Nematode Caenorhabditis elegans and the Brine Shrimp Artemia salina. Journal of Natural Toxins, 11, 165-171.

[16] Barry, T.N. and McNabb, W.C. (1999) Review Article: The Implications of Condensed Tannins on the Nutritive Value of Temperate Forages Fed to Ruminants. British Journal of Nutrition, 81, 263-272.

[17] Min, B.R., Barry, T.N., Attwood, G.T. and McNabb, W.C. (2003) The Effect of Condensed Tannins on the Nutrition and Health of Ruminants Fed Fresh Temperate Forages: A Review. Animal Feed Science and Technology, 105, 3-19. http://dx.doi.org/10.1016/S0377-8401(03)00041-5

[18] Min, B.R., Pinchak, W.E., Fulford, J.D. and Puchala, R. (2005) Effect of Feed Additives on in Vitro and in Vivo Rumen Characteristics and Frothy Bloat Dynamics in Steers Grazing Wheat Pasture. Animal Feed Science and Technology, 123-124, 615-629. http://dx.doi.org/10.1016/j.anifeedsci.2005.04.050

[19] Min, B.R., Attwood, G.T., McNabb, W.C., Molan, A.L. and Barry, T.N. (2005) The Effect of Condensed Tannins from Lotus corniculatus on the Proteolytic Activities and Growth of Rumen Bacteria. Animal Feed Science and Technology, 121, 45-58. http://dx.doi.org/10.1016/j.anifeedsci.2005.02.007

[20] Min, B.R., Pinchak, W.E., Anderson, R.C., Fulford, J.D. and Puchala, R. (2006) Effect of Condensed Tannins Supplementation Level on Weight Gain and in Vitro and in Vivo Bloat Precursors in Steers Grazing Wheat. Journal of Animal 
Science, 84, 2546-2554. http://dx.doi.org/10.2527/jas.2005-590

[21] Min, B.R., Pinchak, W.E., Anderson, R.C. and Hume, M.E. (2006) In Vitro Bacterial Growth and in Vivo Ruminal Microbial Populations Associated with Bloat in Steers Grazing Wheat Forage. Journal of Animal Science, 84, 2873-2882. http://dx.doi.org/10.2527/jas.2005-399

[22] Hervas, G., Perez, V., Girldez, F.J., Mantecon, A.R., Almar, M.M. and Frutos, P. (2003) Intoxication of Sheep with Quebracho Tannin Extract. Journal of Comparative Pathology, 129, 44-54. http://dx.doi.org/10.1016/S0021-9975(02)00168-8

[23] Mashudi, I., Brooks, I.M., Holmes, C.W. and Wilson, G.F. (1997) Effects of Mimosa Bark Extract Containing Condensed Tannins on Rumen Metabolism in Sheep and Milk Production by Grazing Cows. Proceedings of the New Zealand Society of Animal Production, 57, 126-129.

[24] Frutos, P., Raso, M., Hervas, G., Mantecon, A.R. and Giraldez, V.P. (2004) Is There Any Detrimental Effect When a Chestnut Hydrolysable Tannin Extract is Included in the Diet of Finishing Lambs? Animal Research, 53, 127-136. http://dx.doi.org/10.1051/animres:2004001

[25] Spier, S.J., Smith, B.P., Seawright, A.A., Norman, B.B. and Oliver, S.R. (1987) Oak Toxicosis in Cattle in Northern Califonia: Clinical and Pathological Findings. Journal of the American Veterinary Medical Association, 191, 958-964.

[26] Krisper, P., Tisler, V., Skubic, V., Rupnik, I. and Kobal, S. (1992) The Use of Tannin from Chestnut (Castana vesca). In: Hemingway, R.W. and Laks, P.E., Eds., Plant Polyphenols, Plunum Press, New York, 1013-1019.

[27] Chen, W.L. and Anderson, J.W. (1984) Propionate May Mediate the Hypocholesterolemic Effects of Certain Soluble Plant Fibers in Cholesterol-Fed Rats. Proceedings of the Society for Experimental Biology and Medicine, 175, 215-218. http://dx.doi.org/10.3181/00379727-175-41791 